\title{
HSPG2 Gene
}

National Cancer Institute

\section{Source}

National Cancer Institute. HSPG2 Gene. NCI Thesaurus. Code C95446.

This gene is involved in basement membrane architecture. 